\title{
Physical and mechanical studies on binary blended Portland cements containing mordenite-rich tuff and limestone filler
}

\author{
Meriem Meziani ${ }^{1}$, Nordine Leklou ${ }^{2}$, Ouali Amiri ${ }^{2,}{ }^{*}$, and Nasser Chelouah ${ }^{1}$ \\ ${ }^{1}$ Laboratoire de Génie de la Construction et d'architecture, Faculté de Technologie, Université de Bejaïa, 06000 Bejaïa, Algeria \\ ${ }^{2}$ Université de Nantes, Polytech Nantes, GeM, UMR CNRS 6183, 58 rue Michel-Ange, BP 420, 44600 Saint-Nazaire, France
}

Received: 25 September 2017 / Accepted: 25 April 2019

\begin{abstract}
In this research, we made physical and mechanical analyses thanks to which we deduced that the potential of replacing the Portland cement up to $20 \%$ by modernite-rich tuff (TM) and limestone filler (LF). The experimental procedure was done in two main stages. The first stage was dedicated to the pastes, including water requirement, setting time, hydration heat and free $\mathrm{Ca}(\mathrm{OH})_{2}$ content. In the second stage, mechanical and physical properties of mortars, water porosity and pore size distribution were studied. The final results show that LF mixtures closest to the control mixtures unlike the MT mixtures which exhibited a high water demand, less free $\mathrm{Ca}(\mathrm{OH})_{2}$, rapid appearance of the maximum thermal effect, an increase in the total and water accessible porosity, there is also a delay in improving of strength.
\end{abstract}

Keywords: mordenite-rich tuff / cement-based materials / hydration / porosity / mechanical strengths

Résumé. Étude physico-mécanique des mortiers de ciment binaires contenant un tuf riche en mordénite et un filler calcaire. En s'appuyant sur des essais physiques et mécaniques, l'objectif de cette étude est de mettre en évidence l'intérêt du remplacement jusqu'à $20 \%$ du ciment Portland par un tuf riche en mordénite et un filler calcaire. La compagne expérimentale a été réalisée sur deux parties, la première dédiée aux pâtes, évalue le besoin en eau, le temps de prise, la chaleur d'hydratation et la teneur en $\mathrm{Ca}(\mathrm{OH})_{2}$ libre. Dans la seconde partie, les propriétés mécaniques et physiques des mortiers, la porosité à l'eau et la distribution de la taille des pores ont été étudiées. Les principaux résultats ont montré que, à l'opposé des mélanges de tuf riche en mordénite, ceux de filler calcaire semblent être les plus proches au mélange témoin. Les mélanges de tuf se caractérisent par : une forte demande en eau, une baisse de la quantité de $\mathrm{Ca}(\mathrm{OH})_{2}$ libre, une apparition rapide du pic thermique maximal, une amélioration de la porosité accessible à l'eau et de la porosité totale et enfin, un retard dans l'amélioration de la résistance à la flexion et à la compression.

Mots clés : mordénite / matériaux cimentaires / hydratation / porosité / résistances mécaniques

\section{Introduction}

The cement industry has been always among the largest sources of carbon dioxide $\left(\mathrm{CO}_{2}\right)$ emission making up for 5$7 \%$ of the $\mathrm{CO}_{2}$ emissions worldwide [1]. Traditional cements are made from clinker and researches have shown that the fact of reducing the use of clinker by $1 \mathrm{~kg}$ when producing one tone of cement, can reduce the $\mathrm{CO}_{2}$ released in air by $1 \mathrm{~kg}[2]$.

Taking into consideration the environmental protection and the economical aspect, a large variety of supplementary cementitious materials (SCMs) are used

\footnotetext{
* e-mail: ouali.amiri@univ-nantes.fr
}

to substitute either Portland cement clinker in the production of blended cements or cement in the concrete production.

The SCMs are highly attractive options to reduce the problem of $\mathrm{CO}_{2}$ emission which helps to decrease the negative impact on the environment and promote energy savings [1,3]. It is further reported that the demand for cement and concrete will increase from nearly 2 billion tons a year, nowadays to 5.8 billion tons by 2050 [4], much of which should be met through a combination of SCMs and clinker in order to meet environmental restrictions [5].

Since the production of by-products is not expected to increase, there is a great need to explore alternative SCMs to meet the increasing demand. Natural mineral deposits, virtually endless, are some of promising sources of alternative SCMs such as limestone filler and natural pozzolans $[5,6]$. 
The increasing interest in the use of limestone filler in cement-based materials was motivated and justified by the several advantages linked to their use, including: lower costs, a better homogeneity, the worldwide abundance and the ease in controlling quality [7].

The use of pozzolanic materials is gaining a considerable attention because of their ability to react with calcium hydroxide to form compounds which possess cementitious properties. Among the pozzolans which can be used in cement-based materials, the natural zeolites that have emerged as an important binding material in recent years [8].

The pozzolanic activity of the natural zeolites and their incorporation in the blended cements have been studied and several studies revealed that zeolitic minerals enhances the formation of hydration products similar to those produced during cement hydration because of the presence of $\mathrm{Ca}(\mathrm{OH})_{2}[9-11]$.

The possibility of cement substitution by the natural zeolite, mordenite, has been investigated [12-15]. In spite of numerous efforts to investigate the strength properties and durability of concretes and mortars containing natural zeolite $[9,11,12,15-20]$, in our knowledge, in the case of natural mordenite, physical and microstructural behavior like hydration heat, stiffness, water porosity and pore size distribution are not highlighted yet. For such a reason, studies and investigations remain limited in this field. Therefore, this study aims to highlight the benefits of using mordenite-rich tuff as a partial replacement of Portland cement from the physico-mechanical and microstructural point of view. Willing to contribute to the state of an exhaustive knowledge about the basic mechanisms related to mordenite effects, consists on the novelty of our study. We, especially, aim to use the mordenite-rich tuff in construction technology instead of using Portland cement in cement-based materials which was monitored at 7, 28, 90 and 180 days to evaluate its influence on the physicomechanical properties and the hydration of the blended mixes.

\section{Materials, mixtures and curing conditions}

\subsection{Cement, sand and limestone filler}

The main binder used in this study is a cement CEM I 52.5 R, in accordance with European standard NF EN 197-1 (2012) from Saint-Pierre La Cour plant (France) [21]. The cement has a density of $3140 \mathrm{~kg} / \mathrm{m}^{3}$ and a Blaine fineness of $440 \mathrm{~m}^{2} / \mathrm{kg}$. The chemical composition of the cement (PC) is given in Table 1. The Bogue's formula gave the following mass percentages of the main clinker phases: $61 \%$ of $\mathrm{C}_{3} \mathrm{~S}, 15 \%$ of $\mathrm{C}_{2} \mathrm{~S}, 8 \%$ of $\mathrm{C}_{3} \mathrm{~A}$ and $10 \%$ of $\mathrm{C}_{4} \mathrm{AF}$.

Standardized siliceous sand of Leucate (France), with a particle size ranging from 0 to $2 \mathrm{~mm}$ and an absolute density of $2600 \mathrm{~kg} / \mathrm{m}^{3}$ was used to manufacture the mortars NF EN 196-1 (2016) [22].

The Limestone Filler (LF), containing $97.30 \%$ of $\mathrm{CaCO}_{3}$, used is a BETOCARB P2, produced at Erbray's plant (France). This limestone filler is characterized by a Blaine fineness of $397 \mathrm{~m}^{2} / \mathrm{kg}$, an absolute density of $2710 \mathrm{~kg} / \mathrm{m}^{3}$ and a water content of $0.1 \%$.
Table 1. Chemical composition of cement (mass \%).

Tableau 1. Composition chimique du ciment (\% massique).

\begin{tabular}{lc}
\hline Element & Massic content (\%) \\
\hline $\mathrm{SiO}_{2}$ & 20.07 \\
$\mathrm{Al}_{2} \mathrm{O}_{3}$ & 4.86 \\
$\mathrm{Fe}_{2} \mathrm{O}_{3}$ & 3.07 \\
$\mathrm{CaO}$ & 64.25 \\
$\mathrm{MgO}$ & 0.95 \\
$\mathrm{SO}_{3}$ & 3.55 \\
$\mathrm{~K}_{2} \mathrm{O}$ & 1.00 \\
$\mathrm{Na}_{2} \mathrm{O}$ & 0.20 \\
$\mathrm{Na}_{2} \mathrm{O}$ & 0.85 \\
\hline
\end{tabular}

Table 2. Chemical properties of Mordenite-rich tuff (MT) (mass \%).

Tableau 2. Propriétés chimique du tuf riche en mordénite (\% massique).

\begin{tabular}{lc}
\hline Element & Massic content $(\%)$ \\
\hline $\mathrm{SiO}_{2}$ & 64.81 \\
$\mathrm{Al}_{2} \mathrm{O}_{3}$ & 15.58 \\
$\mathrm{Fe}_{2} \mathrm{O}_{3}$ & 2.68 \\
$\mathrm{CaO}$ & 2.85 \\
$\mathrm{MgO}$ & 0.51 \\
$\mathrm{SO}_{3}$ & 0.18 \\
$\mathrm{~K}_{2} \mathrm{O}$ & 3.00 \\
$\mathrm{Na}_{2} \mathrm{O}$ & 3.72 \\
\hline
\end{tabular}

\subsection{Mordenite-rich tuff}

Mordenite-rich Tuff (MT) used in this research was extracted from natural deposits collected in the Tinebdar area, located in the province of Bejaia, Algeria. First, the bulk material was crushed to obtain a material with a particle size smaller than $2 \mathrm{~mm}$. Then, the material was ground for 6 minutes using a vibratory disc mill to obtain a specific surface area similar to that of cement.

The density of mordernite-rich tuff was $2290 \mathrm{~kg} / \mathrm{m}^{3}$ and its specific area was $460 \mathrm{~m}^{2} / \mathrm{kg}$. The chemical composition and physical properties of the finely-ground zeolitic tuff (MT) are shown in Table 2. Powder X-ray diffraction pattern of MT showed the presence of the crystalline phases in a greater quantity of mordenite $(58 \%)$ and a smaller quantity of heulandites $(12 \%)$, albite $(15 \%)$, sanidine $(6 \%)$ and muscovite (9\%) (Fig. 1). The morphology of the MT powder is examined under a scanning electron microscope as shown in Figure 2. A SEM-EDX analysis showed that the mordenite-rich tuff was mainly composed of oxygen, silicon, and aluminum. Whereas, potassium, iron and magnesium were found in minor quantities (Fig. 2).

The particle size distributions of the cement, mordenite-rich tuff and limestone filler were measured by using the laser granulometry are shown in Figure 3. The fractions of the different size classes are summarized in Table 3. 


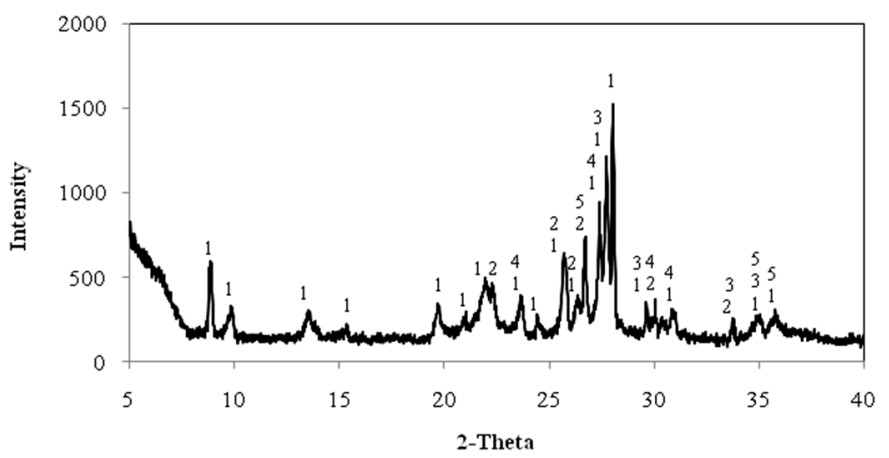

Fig. 1. Powder X-ray diffraction pattern of MT: 1: mordenite; 2: heulandite; 3: albite; 4: sanidine; 5: muscovite.

Fig. 1. Diagramme de diffraction des rayons $X$ de la poudre de tuf: 1: mordénite; 2: heulandite; 3 : albite; 4: sanidine; 5 : muscovite.
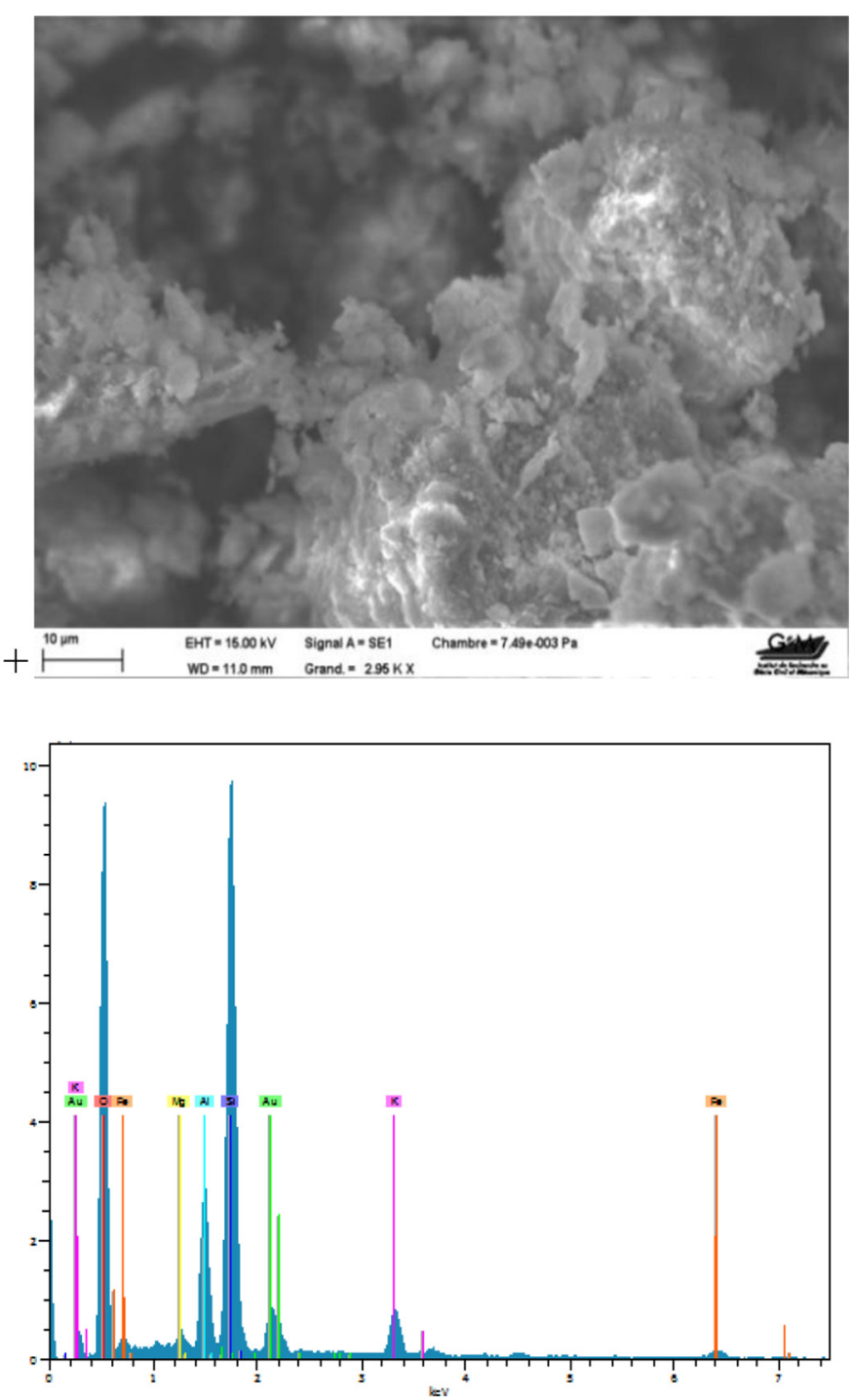

Fig. 2. SEM micrograph and EDX analysis of the MT powder.

Fig. 2. Micrographie par MEB et analyse EDS de la poudre de tuf.

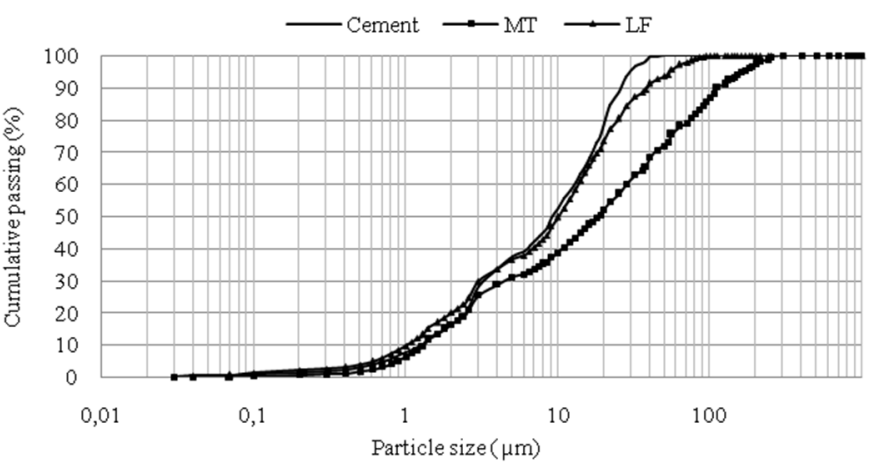

Fig. 3. Granulometry of Portland cement (PC), tuff (MT) and limestone filler (LF).

Fig. 3. Granulométrie du ciment Portland, tuf et filler calcaire.

\subsection{Mixtures and curing conditions}

The studied samples are cement pastes and normalized mortar with a direct replacement of cement by MT or LF on a weight to weight basis at the levels of $0,5,10,15$ and $20 \%$. Nine cement pastes and nine mortars are made by applying the standard mixing, molding and curing procedures stated in the European standard NF EN 1961 (2016) [22]. The water/binder mass ratio (W/B) was 0.35 for pastes and 0.5 for mortars. Physical properties of mortars are shown in Table 4.

The workability tests, conducted using a mortar maniabilimeter LCPC [23], total shrinkage [24], wateraccessible porosity [25], pore size distribution, dynamic Young's modulus [26], and mechanical strength [22] were performed on mortars. In addition, normal consistency, setting time, free $\mathrm{Ca}(\mathrm{OH})_{2}$ content and hydration heat by using isothermal microcalorimetry were measured on cement pastes.

The mortars were cast in prismatic metal molds $\left(40 \times 40 \times 160 \mathrm{~mm}^{3}\right)$, some of them being equipped with stainless steel studs for the measurement of total shrinkage. After pouring, the molds were stored in a humidity chamber at $20 \pm 1{ }^{\circ} \mathrm{C}$ and at a relative humidity above $90 \%$. After 24 hours, the specimens were removed from the molds. The mortars manufactured for mechanical tests were kept in a humidity chamber. The specimens dedicated to the measurement of total shrinkage and Young's modulus were kept in a room at $20 \pm 1{ }^{\circ} \mathrm{C}$ and $50 \pm 5 \%$ of relative humidity. Fresh paste samples were placed in bottles to measure the heat of hydration. Then, the properties of mixtures containing mordenite-rich tuff or limestone filler were compared to those of the control mortar and paste made solely with cement.

\section{Experimental procedures}

\subsection{Pastes of blended cement}

\subsubsection{Normal consistency and setting time}

Normal consistency and setting time analysis of the cement pastes were conducted in accordance with NF EN 196-3 
Table 3. Particle size classes of Portland cement (PC), limestone filler (LF) and tuff (MT).

Tableau 3. Classification des tailles des particules du ciment Portland (PC), filler calcaire (LF) et tuf (MT).

\begin{tabular}{lllc}
\hline & $\mathrm{PC}(\mu \mathrm{m})$ & $\mathrm{LF}(\mu \mathrm{m})$ & $\mathrm{MT}(\mu \mathrm{m})$ \\
\hline $90 \%$ of particles with $\varnothing$ inferior or equal to & 28.92 & 41.53 & 123.6 \\
$50 \%$ of particles with $\varnothing$ inferior or equal to & 10.09 & 11.1 & 19.69 \\
$10 \%$ of particles with $\varnothing$ inferior or equal to & 1.36 & 1.12 & 1.45 \\
\hline
\end{tabular}

Table 4. Composition parameters, density and flow time with a LCPC-maniabilimeter of the different mortars investigated (the indicated ratios are mass ratios, PC: cement; MT: mordenite-rich tuff; LF: limestone filler; B: binder).

Tableau 4. Paramètres de composition, densité et temps d'écoulement mesuré par le maniabilimètre LCPC des différents mortiers (rapport massique; PC: ciment; $M T$ : tuf riche en mordénite; LF : filler calcaire; B : liant).

\begin{tabular}{llllllllll}
\hline & $100 \mathrm{PC}$ & $5 \mathrm{MT}$ & $10 \mathrm{MT}$ & $15 \mathrm{MT}$ & $20 \mathrm{MT}$ & $5 \mathrm{LF}$ & $10 \mathrm{LF}$ & $15 \mathrm{LF}$ & $20 \mathrm{LF}$ \\
\hline $\mathrm{C} / \mathrm{B}$ & 1.00 & 0.95 & 0.9 & 0.85 & 0.8 & 0.95 & 0.9 & 0.85 & 0.8 \\
MT/B & - & 0.05 & 0.1 & 0.15 & 0.2 & - & - & - & - \\
LF/B & - & - & - & - & - & 0.05 & 0.1 & 0.15 & 0.2 \\
W/B & 0.5 & 0.5 & 0.5 & 0.5 & 0.5 & 0.5 & 0.5 & 0.5 & 0.5 \\
Flow time (s) & 4 & 13 & 23 & 60 & 148 & 2 & 2 & 2 & 2 \\
Bulk density & 2.264 & 2.241 & 2.235 & 2.220 & 2.211 & 2.242 & 2.249 & 2.253 & 2.245 \\
Dry bulk density & 2.089 & 2.068 & 2.061 & 2.044 & 2.030 & 2.079 & 2.076 & 2.078 & 2.071 \\
\hline
\end{tabular}

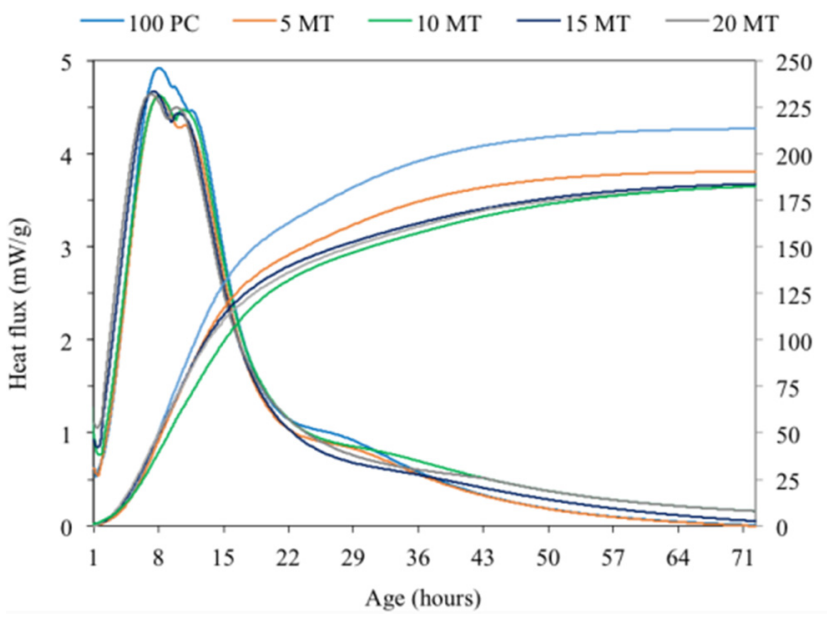

Fig. 4. Heat flux and hydration heat of PC paste and MT pastes.

Fig. 4. Flux de chaleur et chaleur d'hydratation des pâtes de CP et de tuf.

(1995) [27]. Setting time analysis of the blended cements and the reference Portland cement were performed by using an automatic Vicat machine.

\subsubsection{Hydration heat}

The hydration heat evolution rate and cumulative hydration heat of blended cement pastes containing MT or LF were measured with a multi-channel isothermal microcalorimeter of TAM Air type. The tests were performed at a constant temperature nearing $20^{\circ} \mathrm{C}$. TAM Air has eight parallel twinchamber measuring channels: one chamber contains the

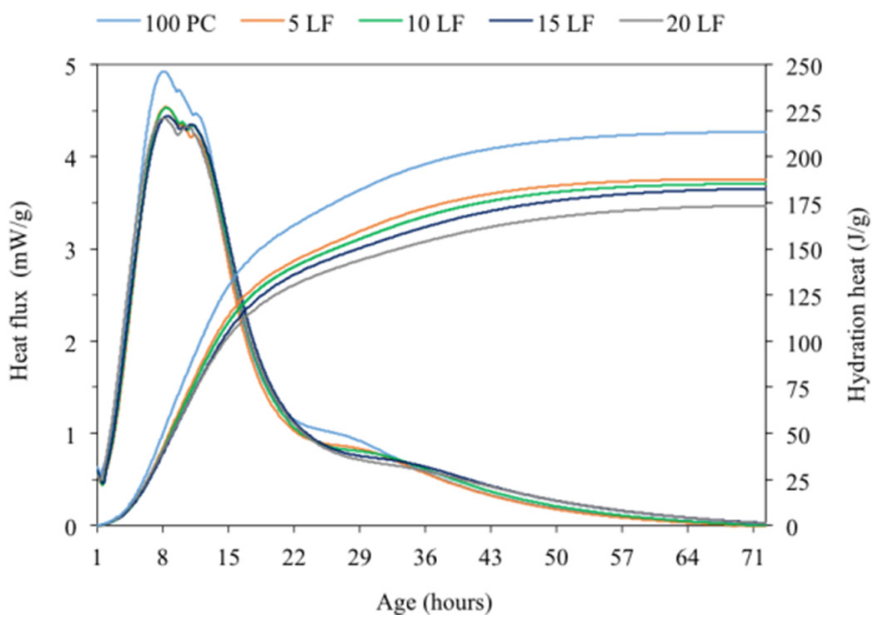

Fig. 5. Heat flux and hydration heat of PC paste and LF pastes.

Fig. 5. Flux de chaleur et chaleur d'hydratation des pâtes de CP et de filler calcaire.

sample, another contains the reference. After mixing homogeneously, the pastes were immediately placed in bottles, weighed and loaded into the microcalorimeter. The hydration heat evolution rate and cumulative hydration heat of blended cements was continuously monitored as a function of time (Figs. 4-6).

\subsubsection{Free $\mathrm{Ca}(\mathrm{OH})_{2}$ content of hardened pastes}

The free $\mathrm{Ca}(\mathrm{OH})_{2}$ content of hardened cement pastes was determined at 7,28 , and 90 days by thermo-gravimetric analysis (TGA) using a Mettler Toledo TGA/DSC 1 

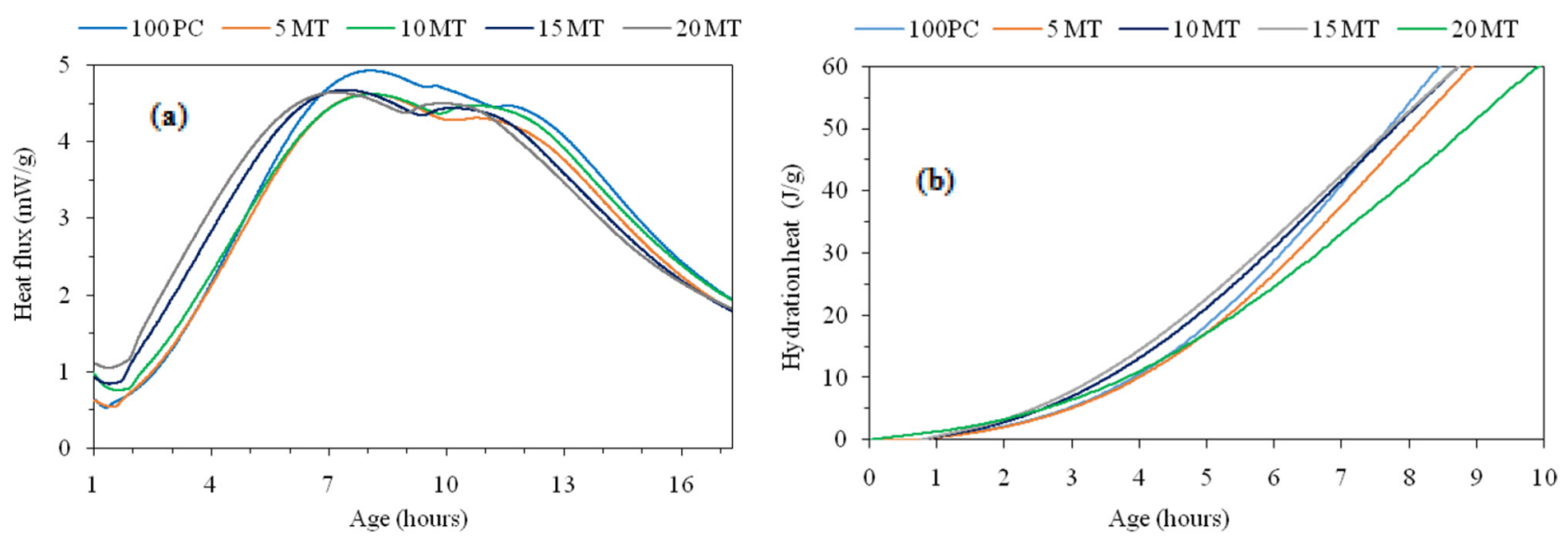

Fig. 6. Detail of heat flux and hydration heat of MT pastes.

Fig. 6. Détail du flux de chaleur et de chaleur d'hydratation des pâtes de tuf.

instrument. At specified test ages, the pastes were crushed and sieved to obtain particles smaller than $80 \mu \mathrm{m}$, then, they were immediately analyzed between room temperature and $1050{ }^{\circ} \mathrm{C}$ at a heating rate of $10^{\circ} \mathrm{C} / \mathrm{min}$ in an atmosphere of carbon dioxide free nitrogen.

\subsection{Mortars}

\subsubsection{Mass variations and total shrinkage}

The total shrinkage and mass variation of mortar specimens were measured using an extensometer with $1 \mu \mathrm{m}$ of precision and a balance with $0.01 \mathrm{~g}$ of precision, respectively. The measurements were conducted from 1 to up to 180 days after the casting of the mortars. The average of three parallel tests was taken as the representative value.

\subsubsection{Dynamic Young's modulus and mechanical strengths}

Dynamic Young's modulus of the mortar specimens was measured according to the European standard NF P 18 414 (2017) [26]. The elastic modulus was calculated by a non-destructive resonance frequency measurement. This frequency was determined via impulse excitation tests with a Grindosonic ${ }^{\circledR}$ device. The mortar prisms were lightly and elastically struck with an impulser and the flexural resonant frequency was recorded with a vibration sensor. The resonance frequency was manually recorded via data acquisition incorporated with the excitation system. For each mortar, the determination of Young's modulus was performed on three specimen-replicates manufactured from the same mixture.

The flexural and compressive strength were determined by means of a $250-\mathrm{KN}$ and $25-\mathrm{KN}$ double automatic compression flexion press-class 1 device in accordance with the European standard NF EN 196-1 (2016) procedure [22]. The reported data represent the average values obtained from three measurements for flexural strength and six for compressive strength.

\subsubsection{Water porosity}

The open porosity of mortars was measured using the water vacuum saturation method recommended by AFPC-AFREM 11-12 (1997) [25]. The samples were placed for four hours in a desiccator which was connected to a vacuum pump in order to remove the air from it. Then, these samples were kept in water for a period of $72 \mathrm{~h}$. After the saturation sequence, the previous samples were weighed thanks to the hydrostatic weighing. Next, the samples were dried for about two weeks in an oven at $105^{\circ} \mathrm{C}$ until the obtention of a constant mass. The porosity $P$ is then calculated using the equation (1).

$$
P=\frac{M_{s a t}-M_{d r y}}{\left(M_{s a t}-M_{w a t e r}\right)},
$$

where $M_{\text {sat }}$ is the mass of saturated mortar sample measured in air ambiance $(\mathrm{g}) ; M_{d r y}$ is the mass of dry sample (g); $M_{\text {water }}$ is the mass of saturated mortar sample measured in water $(\mathrm{g})$.

For each mortar composition, two specimens were tested in order to calculate an average value of open porosity accessible to water.

\subsubsection{Pore size distribution}

The porous structure was performed by mercury intrusion porosimetry (MIP) at 28 and 90 days using an AutoPore IV Micrometrics device. The range of applied pressure corresponded to a pore radius of $10 \mathrm{~nm}$ to $100 \mu \mathrm{m}$. Since oven-drying at $100-105^{\circ} \mathrm{C}$ may cause damage to microstructure and pore system of the hardened mortars, the samples of approximately $3 \mathrm{~cm}^{3}$ of volume were dried in a hot chamber at $60^{\circ} \mathrm{C}$ until obtaining the constant weight to removal moisture. After being dried, the samples were tested by MIP in order to determine the total porosity and the pore size distribution (PSD). 
Table 5. Normal consistency water content and setting time of the cement pastes.

Tableau 5. Consistance normalisée, contenu en eau et temps de prise des pâtes de ciment.

\begin{tabular}{lccccccccr}
\hline & $100 \mathrm{PC}$ & $5 \mathrm{MT}$ & $10 \mathrm{MT}$ & $15 \mathrm{MT}$ & $20 \mathrm{MT}$ & $5 \mathrm{LF}$ & $10 \mathrm{LF}$ & $15 \mathrm{LF}$ & $20 \mathrm{LF}$ \\
\hline Water demand (w/w \%) & 30.5 & 32 & 32.5 & 34 & 35 & 30 & 30 & 30 & 30 \\
Initial setting time (min) & 59 & 63 & 65 & 65 & 72 & 64 & 66 & 72 & 79 \\
Final setting time (min) & 414 & 359 & 339 & 305 & 279 & 355 & 339 & 334 & 334 \\
\hline
\end{tabular}

\section{Results and discussion}

\subsection{Normal consistency and setting time}

The amount of water require for normal consistency of cement pastes and the setting time of the tested samples are shown in Table 5. The results indicate that the water demand of 5, 10, 15 and $20 \mathrm{MT}$ blended-cements was approximately 5, 7, 11 and $15 \%$ higher than the one of $100 \mathrm{PC}$, respectively. Increased water requirement of blended cements when compared to $100 \mathrm{PC}$ is attributed to a higher capacity of MT particles to absorb water.

Initial setting times of the blended cements containing mordenite-rich tuff/limestone filler are slightly greater than that of $100 \mathrm{PC}$. This result is in accordance with a previous report [28]. However, an opposite trend is observed in final setting times. Thus, the final setting times of MT pastes are shorter than that of 100CP by approximately 55, 75, 109 and $135 \mathrm{~min}$ for 5, 10, 15 and 20, respectively. These results are in a good agreement with those of Shon and Kim (2013). They noticed that the presence of zeolite material in the cement system causes a setting acceleration [29]. The latter is probably attributed to a decrease in consistency of the blended cement pastes which is caused by the incessant water absorption by MT particles. So, the setting time decreased when the water demand increased. This acceleration in final setting time can also be attributed to the controlled diffusion which occurs during the pozzolanic reaction of MT.

\subsection{Hydration heat}

The heat flux and hydration heat, shown by kinetic curves in Figures 4 and 5 for cement pastes with varying contents of MT and LF, indicate that the kinetic curves are very close to those of $\mathrm{PC}$ paste. The release of heat is primarily associated with the quick but short-lived hydration of $\mathrm{C}_{3} \mathrm{~S}$ which has a very high intrinsic solubility. When the hydration reactions accelerate and become controlled by nucleation, the acceleration period begins and the heat flow reaches its maximum. Thus, small nuclei of hydration products precipitate out of the pore solution and grow in size. Consequently, the increase in the rate of hydration during the maximum heat flux occurs because the number of nuclei is increasing.

As shown in Figures 4 and 5, the magnitude of heat flux at its maximum and its position on the temporal axis is strongly correlated with the amount of MT and LF added to the reaction system. When the MT and LF content in cement pastes increases, the magnitude of the main heat flux peak decreases. This is due to less cement mass (lower $\mathrm{C}_{3} \mathrm{~S}$ content) after being substituted by the mineral additions.

A detail of the early time hydration of MT pastes compared to that of PC paste is presented in Figure 6 . During the initial period up to $7 \mathrm{~h}$, the heat flux increased as the amount of MT increased in the blended binder (Fig. 6a). The baseline of heat evolution during the induction period increased as the MT content increased. Moreover as illustrated in Figure $6 \mathrm{~b}$, the development of the hydration heat is faster in the initial hydration phase. Apparently, the onset of $\mathrm{C}_{3} \mathrm{~S}$ hydration was accelerated by the presence of MT in the mixture. The earlier occurrence of the peak heat rate is due to the dilution of the system by MT addition. The acceleration stage is related to the adsorption of $\mathrm{Ca}^{2+}$ on the pozzolan (MT), which would allow the $\mathrm{C}_{3} \mathrm{~S}$ to dissolve more rapidly [30,31].

The heat flux at its maximum decreased with increasing amount of LF in the binder and similarly the required time to reach the maximum increased (Fig. 5). An opposite trend is observed with increasing the MT content (Figs. 4 and 6 ). During the first $7 \mathrm{~h}, 10$ and $15 \mathrm{MT}$ increased the hydration heat and accelerated the maximum thermal effect compared to 5, $20 \mathrm{MT}$ and the control cement paste (Fig. 6b). The increase in the MT content causes an increase of the final hydration heat due to the pozzolanic reaction between MT (glassy phases of $\mathrm{SiO}_{2}$ ) and calcium hydroxide released during Portland cement hydration. Nonetheless after $7 \mathrm{~h}$, the strongly exothermic reactions and the ascendant slope for the high curves illustrate that the ordinary cement released somewhat higher hydration heat relatively to the blended cements. These decreased the heat released as the MT content increased. Whereas, the basic shapes of the recorded curves are the same as the curves for the sample without addition. This indicates that using MT as an addition material to system reactions does not change the basic processes as well as the control mechanism of the hydration.

The heat flux peak corresponding approximately to $12 \mathrm{~h}$ associated to the transformation of the trisolfoalumite to the monosulfoalumite phase, was completely missing for the ordinary Portland cement (Fig. 6a). The recorded peak has an insignificant form in $5 \mathrm{MT}$ and LF pastes but is well pronounced in 10, 15 and $20 \mathrm{MT}$ pastes. The time of occurrence of this peak decreased as the amount of MT increased. This emphasized even more the accelerating effect of MT on the hydration process.

At $72 \mathrm{~h}$, the heat flows of 10,15 and $20 \mathrm{MT}$ pastes were higher than that of $5 \mathrm{MT}$ and $100 \mathrm{PC}$; this indicates that the MT was fully involved in the hydration reaction. The limit rate found in Vejmelková et al. (2015) is about $10 \%$ of zeolite [32]. 
Table 6. $\mathrm{Ca}(\mathrm{OH})_{2}$ content $(\%)$ of the hardened cement pastes.

Tableau 6. Contenu en $\mathrm{Ca}(\mathrm{OH})_{2}(\%)$ des pâtes de ciment durcies.

\begin{tabular}{llllllllll}
\hline Cement pastes & $100 \mathrm{PC}$ & $5 \mathrm{MT}$ & $10 \mathrm{MT}$ & $15 \mathrm{MT}$ & $20 \mathrm{MT}$ & $5 \mathrm{LF}$ & $10 \mathrm{LF}$ & 15 LF & 20 LF \\
\hline 7-day & 19.25 & 19.18 & 18.16 & 18.43 & 17.81 & 19.11 & 18.64 & 17.39 & 16.94 \\
28-day & 20.97 & 20.30 & 20.28 & 20.01 & 19.08 & 20.70 & 19.70 & 19.61 & 18.68 \\
90-day & 22.27 & 19.17 & 18.68 & 17.58 & 17.71 & 22.40 & 21.66 & 20.56 & 19.82 \\
\hline
\end{tabular}

\subsection{Free $\mathrm{Ca}(\mathrm{OH})_{2}$ content}

The $\mathrm{Ca}(\mathrm{OH})_{2}$ content in hardened cement pastes was determined by TGA at 7, 28 and 90 days, and the results are shown in Table 6 . We have to note that the content of Portlandite is calculated by Eq. (2) [33]:

$$
\mathrm{Ca}(\mathrm{OH})_{2}(\%)=4,11\left(\mathrm{~L}_{\mathrm{dx}}\right)+1,68\left(\mathrm{~L}_{\mathrm{dc}}-\mathrm{L}_{\mathrm{dca}}\right),
$$

where

$\mathrm{L}_{\mathrm{dx}}(\%)$ : loss of mass due to dehydroxylation of portlandite.

$\mathrm{L}_{\mathrm{dc}}(\%)$ : loss of mass due to decarbonation of calcite.

$\mathrm{L}_{\mathrm{dca}}(\%)$ : loss of mass due to anhydrous materials carbonation.

Factors 4.11 and 1.68 correct for calcium hydroxide formed during hydroxylation and decarbonation, respectively.

According to Table 6 , it can be seen that, free $\mathrm{Ca}(\mathrm{OH})_{2}$ content of blended cement pastes (MT and LF) is lower than that of $100 \mathrm{PC}$ paste at all test ages. This result is the consequence of lower $\mathrm{Ca}(\mathrm{OH})_{2}$ production due to the dilution effect, i.e: the decrease of the clinker content in the LF cements as well as its consumption by the pozzolanic activity of the MT $[34,35]$. Therefore, it can be concluded that after comparing to the $100 \mathrm{PC}$ paste sample, all the MT samples reduced the free $\mathrm{Ca}(\mathrm{OH})_{2}$ content at the three curing periods of times as well as the consumption increased as the level of substitution increased. On the basis of the hydrated cements, the free $\mathrm{Ca}(\mathrm{OH})_{2}$ levels in the cements which contains $5-20 \%$ of MT is $0.4-7.5,3-9$, and $14-21 \%$ are lower than in $100 \mathrm{CP}$ pastes at 7,28 and 90 days, respectively. The free $\mathrm{Ca}(\mathrm{OH})_{2}$ content in the cement paste is very important since portlandite is a reactive compound that may cause durability problems.

The small values of $\mathrm{Ca}(\mathrm{OH})_{2}$ content in the MT blended cement pastes during the first days indicate that pozzolanic action of MT particles occurred slowly during the first stage of hydration. In the other hand, the pozzolanic activity of the mordenite crystals in cementitious systems is associated with the transformation of mordenite into amorphous material able to react in a high$\mathrm{pH}$ medium resulting from presence of $\mathrm{Ca}(\mathrm{OH})_{2}$. The slow pozzolanic reaction in the pastes which contain different amounts of the MT may be due to the lower $\mathrm{pH}$ of the pore solution. This medium is inadequate for the decomposition of the mordenite crystal structure [16,36].

As shown in the results presented in section 4.2 (Hydration heat), at early ages, the onset of alite $\left(\mathrm{C}_{3} \mathrm{~S}\right)$ hydration is accelerated by the presence of the MT in the mixture. So, the $\mathrm{Ca}(\mathrm{OH})_{2}$ produced in the MT mixtures

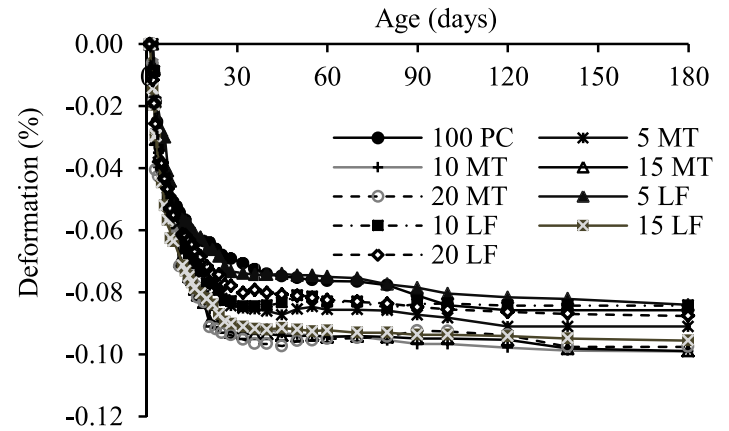

Fig. 7. Total shrinkage versus age.

Fig. 7. Le retrait total fonction du temps.

increases as the content of MT increases; this is due to the dilution effect. But at later ages, the $\mathrm{Ca}(\mathrm{OH})_{2}$ content decreases because of the pozzolanic reaction.

\subsection{Mass variations and total shrinkage}

The Figure 7 presents the total shrinkage test results of the MT and the LF mixtures together with those obtained in the ordinary cement mortar mixture plotted versus age.

The total shrinkage evolves faster during the first four weeks of drying for all the mixes because of their small size favoring the desiccation. At early age, the shrinkage is almost independent of the mortar's composition; the effect of the mineral additions appears only after the first week. On a long term, the LF does not have a significant effect on the total shrinkage where its values meet with those of ordinary cement. The total shrinkage of MT blended cement mixtures is higher than that of the reference sample, and the shrinkage values, at a given age, increases as the MT content increases.

These higher shrinkage values originate from the absorption of part of the mix water by the mordenite particles having an open crystal structure and from the low dynamic modulus of the MT mortars. These results are in contrast with those of Shon and Kim (2013) [29] and Najimi's et al. (2012) [18]. These later found that the replacement of cement at a level of 15 and $30 \%$ by natural zeolite led to an important decrease in shrinkage, about 84 and $64 \%$ at 90 days, respectively.

However, our results are in accordance with those of Jana (2007) who reported that the shrinkage of natural zeolite mixtures with 10 and $20 \%$ Portland cement replacement levels were similar or slightly higher than that of the control mixture [37]. Itim et al. (2011) [17] showed that the substitution of cement by $10 \%$ of natural 


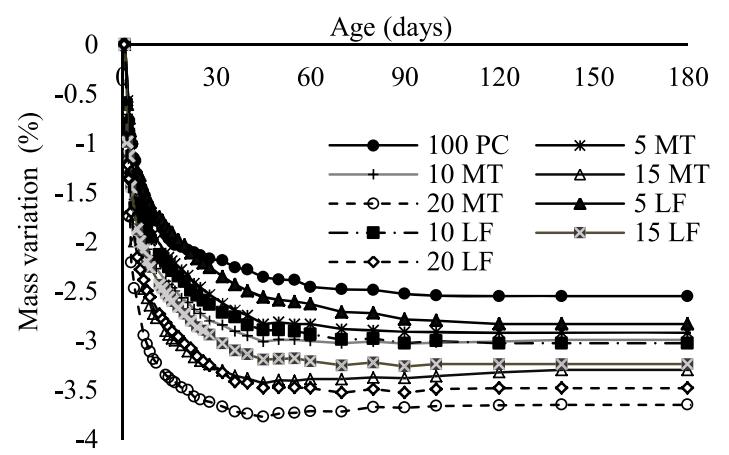

Fig. 8. Mass loss versus age.

Fig. 8. Perte de masse fonction du temps.

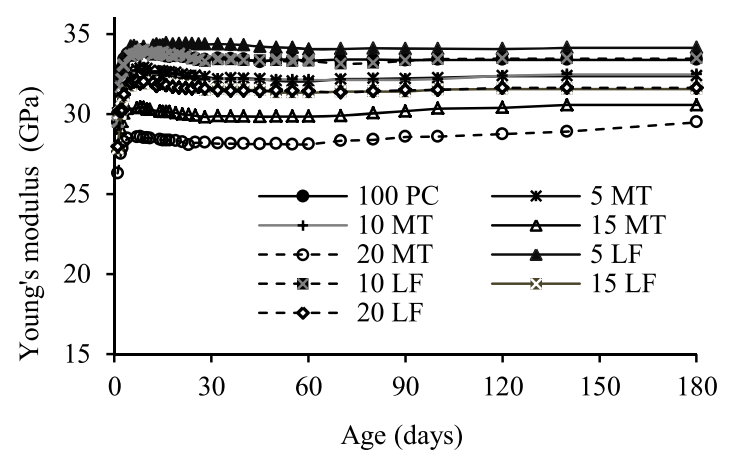

Fig. 9. Dynamic Young modulus versus age.

Fig. 9. Module dynamique de Young fonction de temps.

pozzolan caused a very important shrinkage exceeding that of the ordinary cement. In addition that, they reported that the shrinkage of the $20 \%$ natural pozzolan sample reaches that one without any mineral additions, whereas the shrinkage of those containing $30 \%$ natural pozzolan remains slightly lower.

The mass variation of the different studied mortars is shown in Figure 8. The mass variation curves corresponded approximately to those observed on the shrinkage test. The water evaporation rate is high up to four weeks, but beyond, the mass variation is very low, even almost null. Importantly, it can be noted that the mass variation of the MT and the LF mortars are greater than that of the reference mortar. This increased evaporation was likely related to the decrease in the Portland cement content in these mortars. Thus, the amount of chemically-bound water during the hydration decreased, which increases the free water fraction susceptible to be evaporated.

\subsection{Dynamic Young's modulus}

The data shown in Figure 9 indicate that, compared to the elastic modulus of 100CP mortar, the one of $5 \mathrm{LF}$ is higher, those of $10 \mathrm{LF}$ and $15 \mathrm{LF}$ are equal, whereas that of $20 \mathrm{LF}$ is slightly lower. All of the MT mortars presented an elastic modulus lower than that of 100 PC mortar; however, the difference in strength was not significant. This indicates

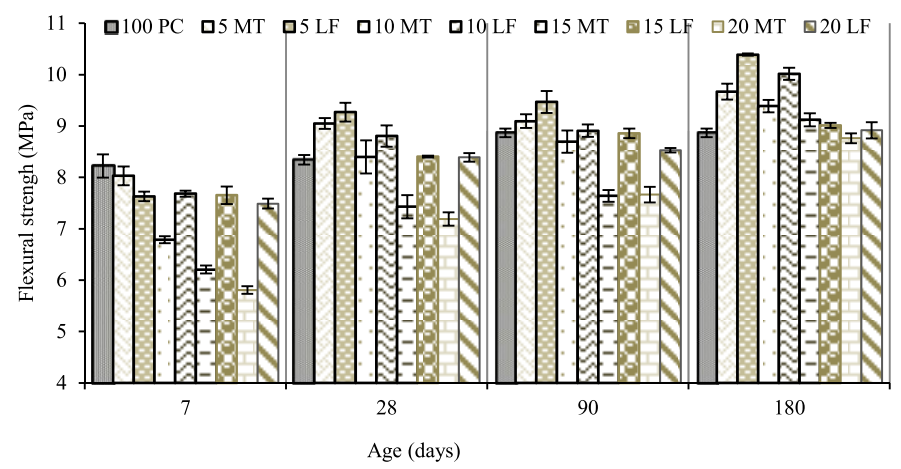

Fig. 10. Flexural strength development of different mixtures.

Fig. 10. Développement de la résistance à la flexion des différentes formulations.

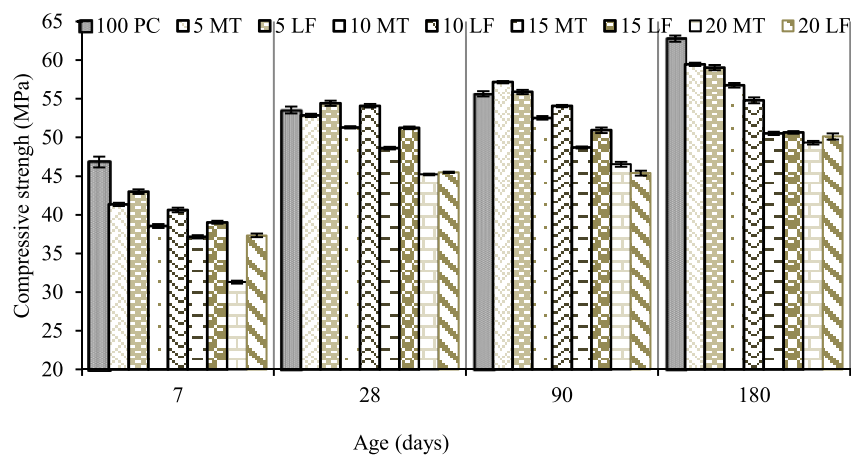

Fig. 11. Compressive strength development of different mixtures.

Fig. 11. Développement de la résistance à la compression des différentes formulations.

that the elastic modulus is not proportional to the compressive strength.

The elastic moduli of MT mortars are lower than that of ordinary mortar which is in agreement with the report of American Concrete Institute Committee (ACIC). The ACIC noted that mortar containing pozzolans typically has a lower modulus of elasticity than a similar mortar without pozzolans [28]. The elastic modulus of the mortar is a function of the modulus of each constituent and their relative mixture proportion. The elastic modulus of the reference mortar is the highest; this is because the modulus of the Portland cement particles is greater than that of lightweight materials particles (MT particles) [38].

\subsection{Flexural and compressive strength of mortars}

The flexural and compressive strengths of the mortars were determined at 7, 28,90 and 180 days, the results are presented in Figures 10 and 11. Apart from 7 days, most of the flexural strength values of the LF mortars were better than that obtained from the reference mixture. For MT mortars, a delay of strength is observed at 7 days as the tuff content increases in the binder. From 28 to 180 days, the 5 and $10 \mathrm{MT}$ samples developed a flexural strength greater 


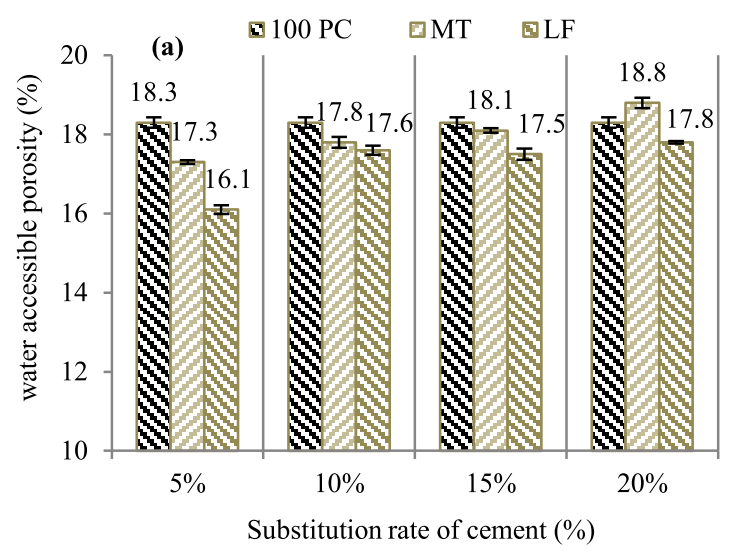

Fig. 12. Water accessible porosity: (a) 28 days; (b) 90 days.

Fig. 12. Porosité accessible à l'eau: (a) 28 jours; (b) 90 jours.

than that of the ordinary cement mortar. The 15 and $20 \mathrm{MT}$ mortars delayed the enhancement of the flexural strength and improved it only after 180 days. Similar results were found by Messaoudene et al. (2012) [39] when volcanic ash were used as mineral admixture. In another study by Kocak et al. (2013), the use of clinoptilolite (zeolite) decreased the flexural strength at all the test ages [40]. The reaching of acceptable levels of mortar strengths after 1 year of cure is attributed to the slow pozzolanic reaction of $\mathrm{M}$.

As expected, the compressive strength increased over time. The rate of increase depended upon the level of mineral addition replacement and age. As seen in Figure 11, it appears that mordenite-rich tuff used in this study have a moderate strengthening effect. Thus, compared to the reference mortar (100 PC), MT mortars have a lower compressive strength which decreases as the MT content increased; apart from $5 \mathrm{MT}$ mortar for which an increasing of compressive strength was observed at 90 days. This is most likely owing to the reduction in $\mathrm{Ca}(\mathrm{OH})_{2}$ levels in the medium despite the increase in MT content [41]. The second possible reason may be the particle size of MT compared to PC and LF particles size distribution. Thus, although $\mathrm{PC}$ and the mineral additions have close specific surface areas, particle size distribution appears to be different; MT is the coarser [42]. Although a constant W/B ratio in the mixtures, the presence of the MT (which consumes water) decreased the workability compared to the $100 \mathrm{PC}$ sample (Table 4 ). This ultimately resulted in an insufficient amount of water available for the pozzolanic reaction. The loss in compressive strength was 5.3, 9.62, 19.5 and $21.44 \%$ for $5,10,15$ and $20 \%$ MT replacement of PC, respectively, at 180 days. This is consistent with Senhaji et al. (2014) study which reported that the natural pozzolan decreased the compressive strengths of mortar at all levels of replacement [19]. The decrease in the strength can also be explained by the fact that more than $15 \%$ of MT content in mortars led to a surplus of the small-sized fractions which separate from Portland cement grains, causing an unpacking of the system and decreasing of the mortar strength [43]. This is in agreement with Benaissa et al. (2016) and Bibi et al. (2008) who found that partial

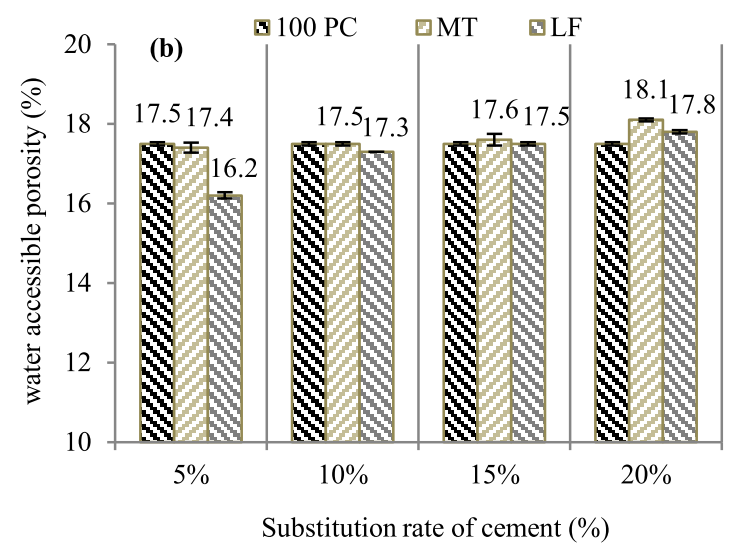

replacement of cement at a level of $10 \%$ was the optimum amount to enhance the compressive strength of concrete $[44,45]$. Similar results were reported by Perraki et al. (2010) who observed that zeolite cements based on CEM I52.5 develop lower strength than pure cement at ages up to 28 days, while they develop higher strength than pure cement at 90, 180 and 360 days [46]. In the other hand, 5 and $10 \mathrm{MT}$ blended cements have acceptable strengths and could match the limits of FD P 15-010 (1997) for CEMI 52.5 Portland cement [47], whereas the 15 and $20 \mathrm{MT}$ mixes could reach the 180 days strength of the commercial Portland cement.

In the case of LF mortars, the results showed that the compressive strength decreased with increasing LF content at all ages. The substitution of Portland cement by LF at a level of 5 and $10 \%$ has significantly increased the 7 and 28day mortars strengths. Such increase of strength may be explained by the very fine particles of $\mathrm{FC}$, which may have acted as nuclei for precipitation of C-S-H and thus increased the degree of cement hydration [48].

\subsection{Water-accessible porosity}

Bulk density, dry bulk density and porosity of the mortar mixtures are given in Table 4 . The results indicate that addition of LF did not have any substantial influence on the bulk density which was almost equal for all mixtures as the difference was less than $1 \%$. The values of MT mortars were at the most $2.5 \%$ lower than the reference mortar. Similar results were seen in the dry bulk density; this most likely related to the porosity of the material and its low specific gravity. From the results of water-accessible porosity test showed in Figure 12, it can be noticed that the porosity of the LF samples are lower than that of $100 \mathrm{PC}$ at 28 days but, nearly equal at 90 days for all the replacement levels. In the other hand, at 28 days, the water-accessible porosities of 5, 10 and $15 \mathrm{MT}$ samples are lower than that of $100 \mathrm{PC}$, apart from $20 \mathrm{MT}$ whose porosity greater by $3 \%$. The porosity of MT samples decreased over the time so that at 90 days, almost the MT mixtures accrued a significant decrease on their porosities to equalize that of $100 \mathrm{PC}$. At this age, the porosity of $20 \mathrm{MT}$ sample is less than that 


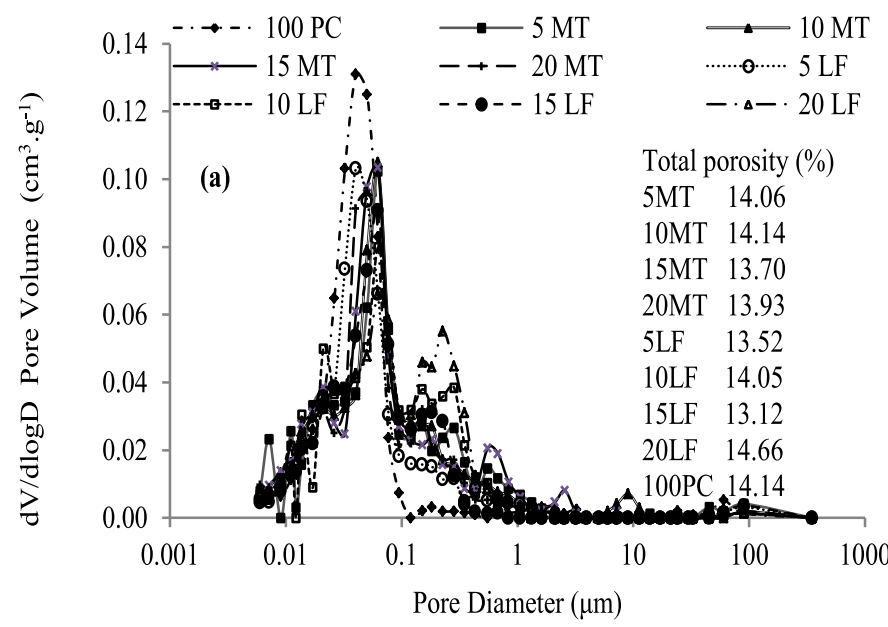

Fig. 13. Pore size distribution and total porosity of mortars: (a) at 28 days; (b) at 90 days.

Fig. 13. Distribution de la taille des pores et porosité totale des mortiers: (a) 28jours; (b) 90jours.

recorded at 28 days by $3 \%$ but higher than that of $100 \mathrm{PC}$ sample by $3 \%$. This low increase in porosity is not deleterious and may be attributed to the porous structure of mordenite-rich tuff. In our point of view, this porosity is non-deleterious because the increase of pore volume, measured by MIP, in $20 \mathrm{MT}$ mortar was mainly due to the small pores of diameter below $0.1 \mu \mathrm{m}$ (Fig. 13). And, it is known that the pores smaller than $0.5 \mu \mathrm{m}$ are more influential on drying shrinkage than on strength and permeability. Also, since the water absorption of the MT is higher than that of cement, increased water absorption is inevitable. The substitution of Portland cement by pozzolans modifies the relative content in hydrates as well as the microstructure. The most important changes concern the transition zone between the aggregate and the matrix paste, where the $\mathrm{Ca}(\mathrm{OH})_{2}$ content decreases and the porosity increases [49].

\subsection{Pore size distribution}

At 28 days, all MT and LF mixtures, except the 20LF, resulted in a lower porosity compared to the $100 \mathrm{PC}$ mortars (Fig. 13a). This result is in consistent with the result of Poon et al. (1999) [50], who reported that at all ages; the porosity of the paste with $15 \%$ zeolite replacement is lower than the one of Portland cement paste having the same water/binder ratio. A drastic change is observed in pore size distribution and total porosity of all mixtures between 28 and 90 days. Clearly, the total porosity of all mixtures decreased as the curing age increased. Indeed, at 90 days, the pores having diameters between 0.1 and $1 \mu \mathrm{m}$ are relatively sealed (Fig.13b). This decrease trend of porosity in the MT mortars indicates an increasing degree of pozzolanic reaction in the blended mixes as the formation and growth of pozzolanic reaction products filled the pores [50]. The difference between the total porosity of 5 and $10 \mathrm{MT}$ mortars and that of $100 \mathrm{PC}$ increased as the curing age increased. For example, the porosity of $5 \mathrm{MT}$ mortar is $0.57 \%$ lower than that of $100 \mathrm{PC}$ mortar at 28 days but is $5.35 \%$ lower than the latter at 90 days. Although the total porosity of 15 and $20 \mathrm{MT}$ mortars decreased at 90 days, it remained slightly greater than the one of 100 PC (Fig.13b). This indicates that the pore reducing ability of the MT is limited and only a small percentage of replacement reduced porosity. The increase in porosity is most likely due to the preservation of microcrystalline structure of zeolite in the hardened mixes.

The results of total pore volume (Fig. 13), obtained by MIP agreed well with the measurement of basic physical properties by water vacuum saturation (Fig. 12). The increase of pore volume in some samples is mainly due to the small pores of diameter below $0.1 \mu \mathrm{m}$ (Fig. 13). It is known that the pore size distribution controls the properties of hardened cementitious systems. Pores larger than $0.5 \mu \mathrm{m}$ are more influential on strength characteristics whereas those smaller than $0.5 \mu \mathrm{m}$ are more influential on drying shrinkage. Therefore, increased total porosity would not be detrimental on strength (Fig. 11) [51].

\section{Conclusion}

Through this study, we show the potential advantages of replacing Portland cement up to $20 \%$ by mordenite-rich tuff and limestone filler in cementitious materials. Based on the physico-mechanical and microstructural test data, the following conclusions can be drawn:

- the LF mixtures seem to be the closest to the control mixture than the MT ones;

- incorporation the MT at 10, 15 and $20 \%$ levels increased the hydration heat up to $7 \mathrm{~h}$ and accelerated the appearance of the maximum thermal effect by allowing the $\mathrm{C}_{3} \mathrm{~A}$ to undergo renewed rapid hydration and convert the ettringite to monosulfoaluminate;

- the pore reducing ability of the MT is limited to a Portland cement replacement rate of $10 \%$. Beyond this level, the microcrystalline structure of mordenite may be preserved in the hardened mixes to slightly increase the porosity;

- the improvement in water accessible porosity of the MT is also limited to up to $10 \%$ replacement of Portland cement. However, the use of the MT at a level up to $20 \%$ is advisable since the water accessible porosity was only slightly affected;

- the blended cements containing the MT exhibited less free $\mathrm{Ca}(\mathrm{OH})_{2}$ in hardened pastes because of the pozzolanic reactivity of the mordenite-rich tuff;

- the MT mortars delayed the enhancement of the flexural strength, so that 15 and $20 \%$ MT have shown their strengthening effect only after 180 days;

- the replacement of ordinary Portland cement by 5 and $10 \%$ of mordenite-rich tuff offers to mortars a suitable compressive strength and could match the limits of FD P 15-010 (1997) for CEMI 52.5 Portland cement. The mixes containing 15 and $20 \%$ of the MT could reach the 180 days strength of the commercial Portland cement; the resulting strengths are satisfactory for structural applications; 
- mortars containing the MT presented a slightly greater shrinkage and a lower Young modulus;

- the water demand of the MT-blended cement pastes increased with the MT substitution ratio because of the micropores inherent to its structure. The addition of the MT delayed the initial setting time but accelerated the final setting time.

In the light of the above and the conclusions drawn, the use of mordenite-rich tuff as a partial substitute for Portland cement presents physico-mechanical and microstructural advantages. The economic virtue is not studied in the present research, but the action of substituting Portland cement by an abundant pozzolanic product will imperatively reduce the cost of manufacturing Portland cement and the emission $\mathrm{CO}_{2}$ into the environment. A more detailed measurement of mortars durability indicators will be made in a follow-up study. Additional studies are underway to assess the feasibility of Portland cement substitution by the MT on concrete.

\section{References}

1. K.H. Yang, Y.B. Jung, M.S. Cho, S.H. Tae, Effect of supplementary cementitious materials on reduction of $\mathrm{CO}_{2}$ emissions from concrete, J. Clean. Prod. 103, 774-783 (2015)

2. W. Al-Kutti, M. Nasir, M.A.M. Johari, A.B.M. Saiful Islam, A.A. Manda, N.I. Blaisi, An overview and experimental study on hybrid binders containing datepalm ash, fly ash, OPC and activator composites, Constr. Build. Mater. 159, 567-577 (2018)

3. T. Hanein, J.L. Galvez-Martos, M.N. Bannerman, Carbon footprint of calcium sulfoaluminate clinker production, J. Clean. Prod. 172, 2278-2287 (2018)

4. N.D. Lagaros, The environmental and economic impact of structural optimization, Struct. Multidiscip. Optim. 58(4), 1751-1768 (2018)

5. U. Environment, K.L. Scrivenera, V.M. Johnb, E.M. Gartner, Eco-efficient cements: Potential economically viable solutions for a low- $\mathrm{CO}_{2}$ cement-based materials industry, Cem. Concr. Res. (2018), DOI: 10.1016/j.cem conres.2018.03.015

6. K.L. Scrivener, A. Nonat, Hydration of cementitious materials, present and future, Cem. Concr. Res. 41, 651665 (2011)

7. D.P. Bentz, C.F. Ferraris, S.Z. Jones, D. Lootens, F. Zunino, Limestone and silica powder replacements for cement: Earlyage 350 performance, Cem. Concr. Compos. 78, 43-56 (2017)

8. S. Bechar, D. Zerrouki, Effect of natural pozzolan on the fresh and hardened cement slurry properties for cementing oil well, World J. Eng. 15(4), 513-519 (2018)

9. A. Terzić, L. Pezo, N. Mijatović, J. Stojanović, M. Kragović, L. Miliciić, L. Andric, The effect of alternations in mineral additives (zeolite, bentonite, fly ash) on physico-chemical behavior of Portland cement based binders, Constr. Build. Mater. 180, 199-210 (2018)

10. I.G. Braz, M.C. Shinzato, T.J. Montanheiro, T.M. de Almeida, F.M. de Souza Carvalho, Effect of the addition of aluminum recycling waste on the pozzolanic activity of sugarcane bagasse ash and zeolite, Waste Biomass Valoriz., 1-21 (2018)
11. N.A. Ulload, H. Baykara, M.H. Cornejo, A. Rigail, C. Paredes, J.L. Villalba, Application-oriented mix design optimization and characterization of zeolite-based geopolymer mortars, Constr. Build. Mater. 174, 138-149 (2018)

12. M. Sedlmajer, J. Zach, J. Hroudová, P. Rovnaníková, Possibilities of utilization zeolite in concrete, Int. J. Civ. Environ. Struct. Constr. Archit. Eng. 9(5), 525-528 (2015)

13. H. Baykara, M.H. Cornejo, R. Murillo, A. Gavilanes, C. Paredes, J. Elsen, Preparation, characterization and reaction kinetics of green cement: Ecuadorian natural mordenitebased geopolymers, Mater. Struct. 50(3), 1-12 (2017)

14. A.U. Elinwa, M. Umar, X-ray diffraction and microstructure studies of gum Arabic-cement concrete, Constr. Build. Mater. 156, 632-638 (2017)

15. D. Nagrockiene, G. Girskas, G. Skripkiunas, Properties of concrete modified with mineral additives, Constr. Build. Mater. 135, 37-42 (2017)

16. D. Caputo, B. Liguori, C. Colella, Some advances in understanding the pozzolanic activity of zeolites: The effect of zeolite structure, Cem. Concr. Compos. 30, 455-462 (2008)

17. A. Itim, K. Ezziane, E.H. Kadri, Compressive strength and shrinkage of mortar containing various amounts of mineral additions, Constr. Build. Mater. 25, 3603-3609 (2011)

18. M. Najimi, J. Sobhani, B. Ahmadi, M. Shekarchi, An experimental study on durability properties of concrete containing zeolite as a highly reactive natural pozzolan, Constr. Build. Mater. 35, 1023-1033 (2012)

19. Y. Senhadji, G. Escadeillas, M. Mouli, H. Khelafi, Benosman, Influence of natural pozzolan, silica fume and limestone fine on strength, acid resistance and microstructure of mortar, Powder Technol. 254, 314-323 (2014)

20. V.F. Rahhal, Z. Pavlík, A. Tironi, C.C. Castellano, M.A. Trezza, R. Černý, E.F. Irassar, Effect of cement composition on the early hydration of blended cements with natural zeolite, J. Therm. Anal. Calorim. 128(2), 721-733 (2017)

21. NF EN 197-1, Ciment-Partie 1 : composition, spécifications et critères de conformité des ciments courants, Comité européen de normalisation, Bruxelles, 2012

22. NF EN 196-1, Méthodes d'essais des ciments. Partie 1: détermination des résistances mécaniques, Comité européen de normalisation, Bruxelles, 2016

23. NF P18-452, Mesure du temps d'écoulement des bétons et des mortiers aux maniabilimétres, AFNOR, Paris, 1988

24. NF P15-433, Méthode d'essais des ciments. Détermination du retrait et du gonflement, AFNOR, Paris, 1994

25. AFPC-AFREM 11-12 Compte-Rendu des journées techniques. Durabilité des bétons, INSA, Toulouse, 1997

26. NF P18-414, Essai des bétons. Essais non destructifs. Mesure de la fréquence de résonance fondamentale, AFNOR, Paris, 2017

27. NF EN 196-3, Méthodes d'essais des ciments. Partie 3: Détermination du temps de prise et de la stabilité, Comité européen de normalisation, Bruxelles, 1995

28. ACI 232.1R-12, Report on the use of raw or processed natural pozzolans in concrete, American Concrete Institute, Farmington, USA, 2012

29. C.S. Shon, Y.S. Kim, Evaluation of west Texas natural zeolite as an alternative of ASTM Class F fly ash, Constr. Build. Mater. 47, 389-396 (2013)

30. V. Tydlitát, J. Zákoutsky, R. Cern, Early-stage hydration heat development in blended cements containing natural zeolite studied by isothermal calorimetry, Thermochim. Acta 582, 53-58 (2014) 
31. R. Snellings, G. Mertens, Ö. Cizer, J. Elsen, Early age hydration and pozzolanic reaction in natural zeolite blended cements: Reaction kinetics and products by in situ synchrotron X-ray powder diffraction, Cem. Concr. Res. 40, 17041713 (2010)

32. E. Vejmelková, D. Konakova, T. Kulovaná, M. Keppert, J. Zumar, Engineering properties of concrete containing natural zeolite as supplementary cementitious material: Strength, toughness, durability, and hygrothermal performance, Cem. Concr. Compos. 55, 259-267 (2015)

33. S.M. Monteagudo, A. Moragues, J.C. Gálvez, M.J. Casati, E. Reyes, "The degree of hydration assessment of blended cement pastes by differential thermal and thermogravimetric analysis. Morphological evolution of the solid phases", Thermochim. Acta 592, 37-51 (2014)

34. E. Kontori, T. Perraki, S. Tsivilis, G. Kakali, Zeolite blended cements: Evaluation of their hydration rate by means of thermal analysis, J. Therm. Anal. Calorim. 96, 993-998 (2009)

35. T. Perraki, G. Kakali, F. Kontoleon, The effect of natural zeolites on the early hydration of Portland cement, Microporous Mesoporous Mater. 61, 205-212 (2003)

36. B. Drzaj, S. Hocevar, M. Slokan, A. Zajc, Kinetics and mechanism of reaction in the zeolitic tuff- $\mathrm{CaO}-\mathrm{H}_{2} \mathrm{O}$ systems at increased temperature, Cem. Concr. Res. 8, 711-720 (1978)

37. D. Jana, A new look to an old pozzolan: Clinoptilolite- A promising pozzolan in concrete, Proceedings Conference of the Twenty-ninth Conference on Cement Microscopy, Quebec, 2007

38. D. Richard, A. Helmuth, J. Rachel, The nature of concrete, in: J.F. Lamond, J.H. Pielert (Eds.), Significance of testes and properties of concrete and concrete-making materials STP 169D, ASTM International, 2006

39. I. Messaoudene, L. Molez, D. Rangeard, R. Jauberthie, A. Naceri, Mortiers à base de sable pliocène et de ciments aux ajouts: fillers de déchets industriels et cendres volcaniques, Matériaux \& Techniques 100, 377-386 (2012)
40. Y. Kocak, E. Tasc1, U. Kaya, The effect of using natural zeolite on the properties and hydration characteristics of blended cements, Constr. Build. Mater. 47, 720-727 (2013)

41. R. Siddique, Effect of volcanic ash on the properties of cement paste and mortar, Resour. Conserv. Recycl. 56, 66-70 (2011)

42. T.K. Erdem, C. Meral, M. Tokyay, T.Y. Erdogan, Use of perlite as a pozzolanic addition in producing blended cements, Cem. Concr. Compos. 29, 13-21 (2007)

43. M.J. Shannag, High strength concrete containing natural pozzolan and silica fume, Cem. Concr. Compos. 22, 399-406 (2000)

44. M. Benaissa, K. Bendania, N. Belas, K. Belguesmia, H. Missoum, Influence of adding bentonite on mortars and selfcompacting concrete properties, Matériaux \& Techniques 104, 12 (2016)

45. M. Bibi, M.A. Chikouche, K. Ait Tahar, Influence of sandy or/and muddy clay additions, on the properties of materials cementing, Matériaux \&Techniques 96, 165-172 (2008)

46. T. Perraki, E. Kontori, S. Tsivilis, G. Kakali, The effect of zeolite on the properties and hydration of blended cements, Cem. Concr. Compos. 32, 128-133 (2010)

47. FD P 15-010 Liants hydrauliques. Guide d'utilisation des ciments, AFNOR, 1997

48. L.G. Li, A.K.H. Kwan, Adding limestone fines as cementitious paste replacement to improve tensile strength, stiffness and durability of concrete, Cem. Concr. Compos. 60, 17-24 (2015)

49. I. Odler, Hydration, setting and hardening of Portland cement, in: P.C. Hewlett (Ed.), Lea's chemestry of cement and concrete, Elsevier B, Oxford, UK, 1988

50. C. Poon, L. Lam, S. Kou, Z. Lin, A study on the hydration rate of natural zeolite blended cement pastes, Constr. Build. Mater. 13, 427-432 (1999)

51. B. Uzal, L. Turanl, Blended cements containing high volume of natural zeolites: Properties, hydration and paste microstructure, Cem. Concr. Compos. 34, 101-109 (2012) 